\title{
Professionalization of Media Practice in Nigeria: An Analytical Survey
}

\author{
Chinelo Edith Ude-Akpeh And Comfort Ojoma Ukwella \\ Nta Television College Jos, Plateau State, Nigeria.
}

\begin{abstract}
This is an analytical survey study which X-rayed the professionalization of media practice in Nigeria. Anchored on the social responsibility and Development Media theories of the press, the paper among other things ascertained the prevailing professionalism status of Journalism practice in Nigeria, examine the preconditions for a career to be identified as a profession, ascertained the correlation between journalism practice and preconditions for identifying a career as a profession, ascertain the processes of professionalization and ascertained the relationship between media practitioners and professionalism. The study provided a cursory look at the mass media landscape in Nigeria. The concepts of professionalism, profession and professionalization were critically $X$-rayed and differentiated. The study adopted a focus group discussion (FGD) method and held 3 sessions of the FGD at Onitsha, Awka and Nnewi. Using the explanation building technique as a method of data presentation, the study found, based on the preconditions for an occupation to be identified as profession, that media practitioners in Nigeria were not yet professionals. It recommended that the NUJ should regulate the entry requirements into the profession and ensure strict compliance to the code of conduct of the profession.

Key Words: Professionalization, Journalism, Profession, Media, Practitioners and Nigeria
\end{abstract}

\section{INTRODUCTION}

Media practitioners, according to Tsebee (2011), are commonly referred to as the people who engage in the occupation of working in the newspaper, magazines, radio and television industries (mass media). Mass Media practitioners are, therefore, the people through which the media, otherwise called the "fourth estate", perfume the watchdog function, in terms of surveillance, correlation, and transmission of cultural heritage from one generation to another, education, development and general progress of society (Lasswell, 1948, cited in FabUkozor (2011).

In a related development, journalism is the occupation of reporting, writing, editing, photographing or broadcasting news or of conducting any news organization as a business (Duyile, 2007). According Nile (2015), journalism is the work of finding, creating, editing and publishing news or materials for a newspaper, magazine and broadcast industries. Journalism means writing for newspapers or magazines. It is the communication of information through writing in periodicals and newspapers. The people have an inborn desire to know what's novel or new. This curiosity is satisfied by the journalists through their writing in the newspapers and journals on current affairs and news. Journalism is the occupation of reporting, writing, editing, photographing or broadcasting news or of conducting any news organization as a business. Asfor (1991, p. 21) explains that "Journalism" is derived from the word "Journal" which means a daily register or a daily - book containing each day's business or transaction. This includes newspapers no matter whether they are published daily or weekly. It also means a magazine to whatever section of the audience it caters to.

Bond (1973), cited in Uduaka and Nnadi (2007, p. 87) also explains as follows:

The word journalism is derived from Journal which means a daily register or a diary. Today the word journal also connotes a newspaper, published every day or even less often or a magazine. Thus Journalism means, the communication of information regarding the events of a day through written words, sounds or pictures. And a journalist is a person who writes for or conduct a newspaper or magazine. He is also called a press man.

While journalism is limited to the art and science of gathering, procuring, editing and dissemination of news and information, media practice encompasses both journalism and other workers in a media organization. Nevertheless, journalism and media practitioners are interchangeably used in this study to mean the same thing. Regardless of the important position and functions of media practitioners in the society, it is still a subject of agitation that media practitioners are not yet professionals, hence the need for professionalization of the practice. Adaja (2012, p.15) adds that the invention of the new media, especially the internet, has revolutionized and redefined who is a media practitioner and thus further makes it difficult to ascribe media practitioners the status of professionals. 
For instance, Olajide, Talabi and Ogundeji (2012, p. 7) conducted a study on effects of Non-Professionalism in Nigeria Journalism, and report as follows:

For a very long time, Nigeria scholars in various fields of endeavour have argued on the trade journalism. This issue bothers on the fact that every dicks and harry dabbles into this profession either to make ends meet, practice for political ambition or easily pick it up at the time of employment recession in Nigeria. Journalism as a profession especially in Nigeria has been hijacked by quacks or subtly put, people from other professional careers at the detriment of this noble profession. In light of this, the paper raised who is a professional journalist and how does non-professionalism affect the practice of journalism in Nigeria. Journalists in Nigeria were used as participants while survey method was used to carry out the research.

Results of the study showed that Nigeria journalists are yet to attain the standard of professionalism. The criteria for membership have made journalism in Nigeria an - all- comers affairs (Adaja, 2012). Also, the absence of a prescribed qualifying text has made it difficult to moderate the standard of journalism practice in Nigeria.

In his article, “why Journalism isn't a profession,” Smith (1970), cited in Oso (2012,p.86), argues that:

As late as 1950s, more than half of the reporters lacked a college degree... Journalism has been a craft- in rare moments-an art- but never a profession. It depends too much on the perception of the practitioner rather than on the acquisition of technical knowledge and skills. The techniques of reporting can be much more easily taught than such human qualities and they can be best learnt in an-apprentice -like situation rather in classroom.

Perhaps, it may be in rapid response to the foregoing comments that the process of professionalization of the media practitioners (journalism) stated. Smith (1970), cited in Oso (2012, p.87) acknowledged the process when he said:

Since that time (1950s) there has been increased emphasis on professionalism in journalism; the proliferation in journalism; witnessed the growth of journalism schools; the proliferation of turgid articles on the subject; and the pre-occupation with objectivity and other ethical issues.

Conversely, Tsebee(2012) in his findings on the paper, media ethics: professionalism and coverage of the APO killings in Abuja, Nigeria explains that Nigeria media practitioners indulge in professionalism in their news reportage.

In the Nigerian context, the scene of mass media practitioners' professionalization, as described by Smith (1970), is similar. Thus, this study intends, among other things to:

1. ascertain the prevailing professionalism status of journalism practice in Nigeria;

2. examine the circumstances surrounding journalism as a profession in Nigeria;

3. ascertain the pre-conditions for identifying a career as a profession;

4. ascertain the co-relation between journalism practice in Nigeria and the pre-conditions for accepting a career as a profession;

5. ascertain the factors inhibiting journalism practice as a profession in Nigeria.

\section{Theoretical underpin}

The work is anchored on two communication theories - the social Responsibility Theory and Development Media Theory

1. Social Responsibility Theory: As a result of the shortcoming of the libertarian theory of the press, the Hutchins Commission of Freedom of the Press set up in the United States of American in 1947 recommended that, apart from ensuring and preserving press freedom, the press is also expected to observe certain social standards and responsibilities in performing their professional functions. Thus, the emergence of social responsibility theory, according to Siebert (1956) as cited by Folarin (1998, p.28) was premised on six functions.

i To sever the political system by making information, discussion and consideration of public affairs generally accessible.

ii To inform the public to enable it to make self determined action.

iii To protect the rights of the individual by acting as watchdog over the government.

iv To serve the economic system, for instance the bringing together buyers and sellers through the medium of advertising.

v. To provide good entertainment, whatever "good" may mean in the culture at any point in time.

vi To preserve financial autonomy in order not to become dependent on special interests and influences.

2. Development Media Theory: The theory seeks to prescribe the function of the press in developing nations of the world. The theory posits that the media/press must provide such platforms that can accelerate the development of their respective nations. The major thrusts of the theory, according to McQuail (1987) as cited by Folarin (1998) are that: 
i Media must accept and carry out positive development tasks in line with nationally established policy;

ii Freedom of media should be open to economic priorities and development needs of the society;

iii Media should give priority in their content to the national culture and language(s);

iv Media should give priority in news and information to links with other developing countries which are close geographically, culturally or politically;

$\mathrm{v}$ Journalist and other media workers have responsibilities as well as freedom in their information gathering and dissemination tasks.

vi In the interest of development ends the state has a right to intervene in, or restrict, media operation, devices of censorship, subsidy and direct control can justified.

Thus, the above two theories present the media institution as central and germane to the existence of the society. And, for the media institution to perform its social responsibility and development functions, it must be peopled by professionals who understand and can uphold central media tenets such as impartiality, truthfulness, balance reporting, fairness to all parties, it is only through this that the media institution/journalism can live up to the expectations of a profession.

\section{Understanding Mass Media Landscape in Nigeria}

Ndolo (2005, p.41) informs that aside from books, newspaper is the oldest medium of mass communication. Ndolo (2005) explains that in Nigeria, newspaper publishing arrived in 1859, when Reverend Townsend Henry of the church missionary society (CMS) founded the first newspaper - Iwe Irohin fun Awon Ara Egba Ati Yoruba or Iwe Irohin(Meaning in English, A newspaper of information for the Egba speaking people of the Yoruba). Coker (1968), cited in Adaja (2012, p16) quoted Henry Townsend as stating that the mission of the paper was to get the people to read; to beget the habit of seeking information by reading." Thus, the desire of the British Missionaries as well as the British humanitarian movements, at the time of success in operations in Nigeria and other parts of Africa led to the establishment of newspaper in their colonies across Africa.

In 1863, a Jamaican Mulatto printer and journalist, a settler in Lagos, launched the Anglo-African - a newspapers regarded by some people as the first (Ndolo, 2005). Several short-lived newspapers were to follow up till the 1930s when the Nigerian newspaper industry grew to another level:

- Lagos Time and Gold coast Advertiser (1880-1883) by Richard Blaize and later taken over by Andrew Thomas;

- The Eagle and Lagos Critic (March 1883-Oct. 1883) by Owen Macaulay;

- The Mirror (1887-1888)-by Adulphus Mark,

- The Lagos weekly (1891-1930) by John Payne Jackson.

- The Nigeria Pioneer (1914-1937) by Kifoye Ajasa.

- The African Messenger (1921-1924) by Ernest Ikoli. The paper later came to be renamed The Nigerian Daily Time.

- $\quad$ The Lagos daily News (1928-1936) by Obademi.

Ndolo (2005, pp.42-42) explains that in Nigeria, agitations against colonial rule and the rise in political awareness and politicking gave rise to the establishment of various nationalism commercial newspapers.

The West African Pilot, published by Dr. Nnamdi Azikwe in 1937, Ushered in the Zikist Era, which was to see a Chain of Newspapers. The paper was a trailblazer with a front page badge of "show the light and people will find the way." It became the prototype of modern journalism in today's Nigeria.

Other newspapers in the Zikist Chain include:

- $\quad$ Eastern Nigeria Guardian established in 1940 at Port-Harcourt as the daily newspaper in Eastern Nigeria.

- Southern Nigeria Defender established at Warri in 1943.

- Daily Comet established in 1944 at Kano.

- Nigerian Spokeman established in 1945 at Onitsha.

- $\quad$ Northern Advocate established in Jos in 1949.

There were also other nationalist papers:

The Nigerian Tribune was founded in 1949 by Late Chief Obafemi Awolowo. The Daily Service was founded by the Nigerian Youth Movement headed by Ernest Ikoli and the Nigerian Citizen was published by the Northern Peoples Congress (NPC) The Daily Times was founded in 1947 by the Daily Mirror group of London. By Independence in 1960, the Daily Times had emerged as one of the leading papers with government owning $60 \%$ and the private individuals owning $40 \%$. According to Ekwelie (1985), 
When Nigeria gained national independence in 1960, it had an array of colourful newspapers. Some of them appeared daily, some less frequently, some were owned by government, some by political parties but a lot by private enterprise. In quality editorial output, the West African Pilot seemed to lead the way but as a successful commercial venture, the Daily Times was on top of the heap. Such dailies as the Nigerian Outlook and the Nigerian Citizen seemed undermined by the ambivalence of being in name, government organs but, in reality, party voices.

In today's Nigeria, the Daily Times is comatose having been privatized; the Nigerian Citizen is the only existing Federal Government newspaper but renamed the New Nigeria. State government owned Newspapers are in various stages of disease, some sporadic, some epileptic, some comatose and others dead.

Nigeria however, has vibrant private print media. Newspapers abound that cover all areas of journalistic interests from hard news to soft sell. Some of the privately owned newspapers include: The Guardian, This Day, The Sun, The Daily Champion, The Punch, National Interest, The Comet, Today's Sports etc. For broadcast media, Ndolo (2005) writes that radio broadcasting in Nigeria dates back to $19^{\text {th }}$ December, 1932, When the BBC set up an experimental radio-receiving station in Lagos, while the television broadcasting in Nigeria and African as a whole stated on October $31^{\text {st }}, 1959$ with the establishment of the Western Nigeria Television (WNTV) as an arm then of the Western Nigeria Services.

Today, the Federal Government and all the States of the Federation have both radio and television stations. Private radio and television stations in Nigeria complement the efforts of the Government broadcast stations in the information needs of Nigeria.

\section{Who is a Media Practitioner?}

According to Ansari (2011), media practitioners are the professionals who are different, in the sense that they are users of information as communicators. Ansari (2011) further states that their requirement of information is very vast and diversified. They are very time conscious. For satisfaction of their needs, they interact with varied type of information system and personal sources. For Answers com., media practitioners practice the media. They would be the one who write the newspaper articles and also play your favourable music on the radio.

Basically, one may be tempted to regard media practitioners as the totality of persons working in a mass media outfit. This, using for example a newspaper industry, will include the gateman, typists, reporters, editors, production office, among others. However, the definition provided by Answers.com., tends to limit media practitioner to reporters and editors only (those who write article in the newspapers). This, to a large extent corroborates the earlier definition provided by Ansari (2011), which sees media practitioners as users of information. The users of information in mass media industries are the journalists. To this extent, mass media practitioner, in the context of this study, are interchangeably used with journalists.

\section{Professionalism and media practitioners}

The term professionalism needs to be defined for us to operate on the same frequency. According to The Random House Dictionary of the English Language, the word professionalism means, professional character, spirit, or methods. The standing practice, or methods of a professional, as distinguished from an amateur Professionalism, has been variously defined and a number of criteria of professionalism abounds in the research literature. Onah (1992), Volimer and Mill (1966) cited in Onah (1996, p219) defined it as the ideology and associated activities that can be found in many diverse occupational groups where members aspire to professional status. But Carr-Sanders and Wilson (1933), cited in Fab-Ukozor (2011) defined professionalism simply as a process of change (as opposed to ideological principles) by which the professional minded occupations go about achieving those characteristics that will gain for them the professional status they desire.

According to Bel-Molokwu and C.De Aguomba (1990), professionalism among media practitioners or journalist stands on nine major pillars:

1. "Recognition of the sacredness of truth and freedom.

2. Avoidance of libel, sedition, deliberate distortion, bad taste and salaciousness.

3. Displaying the spirit of retracting facts when wrong.

4. Balance reporting and presenting both sides of the coin.

5. Burying personal biases or sectional interests.

6. Respect for societal norms and laws of the land.

7. Keeping clear of corrupt practices.

8. Protecting your source of formation at all cost.

9. Sporting a good personality." 
Similarly, when we speak of professionalism we are always reminded of McLead and Hawled, Jr'. study on professionalism conducted in 1964 in the U.S.A. among some American newsmen (cited in Odumegwu 2000). In the study they stated the eight criteria that must be satisfied for an occupation to become a profession, namely:

1. It must perform a unique and essential service.

2. It must emphasize intellectual techniques.

3. It must have a long period of specialized training to acquire a systematic body of knowledge based on research.

4. It must be given a broad range of autonomy.

5. Its practitioners must accept broad personal responsibility for judgments and actions,

6. It must place great emphasis on service than on private economic gain

7. It must develop a comprehensive self governing organization, and

8. It must have a code of ethnics which has been clarified and interpreted by concrete cases, (McLeod and Hawley Jr.. 1964).

Mott writing about occupational professionalism enumerated essential qualities of professionalism as: higher than that of routine or perfunctory trade, as well as loyalty to and zeal for the occupation or calling which result in solidarity."

\section{Professionalism and Professionalization in Media Practitioners}

Volmer and Mills(1966), cited in Nwosu (1996, p244) aver that professionalism refers to the ideology and associated activities that can be found in many diverse occupational group where members aspire to professional status. It has also been define as "a set of principles, ideas, attitude and activities that characterize and guide the bebaviour of members of any occupational group which is anxious to gain and maintain both ingroup and out group acceptance of its professional standing" (Nwosu, 1984, p. 53).

Professionalism is therefore more or less a state of mind, a world view, an aspiration backed up with specialize activities and an approach to our jobs that makes us to be recognized and respected by the society as professional group, as opposed to just another occupational group. It bestows pride on members of the group, and makes them stand out from the crowd of other occupational groups. It also brings with a lot of duty, responsibility and societal expectations which make the true professionals to always be on their toes, on their guard and always ready to fight for and protect the ideals for which the profession is known. Professionalism, on the other hand, can simply be describe as a process of change through which members of the professionally minded occupational groups, like advertising, go about achieving those characteristics and objectives that will gain for them the improve professional status they desire and work for. So, while professionalism can be seen as an ideal term, professionalization is the practical process through which we keep working towards the attainment of reasonable high level of ideal. Professionalization is also a continuous through which we can achieve improved professionalism. Since professionalism is an ideal term can never be achieved by man who is an imperfect animal, true professionals must continually engage in the process of professionalization to remain relevant and effective.

The process of professionalization includes, among other things, continuous education, continuous acquisition and updating of professional skills, active belongingness and participation in the activities of relevant professional bodies or associations, transparent honesty and ethical/responsible performance of our professional duties. Media profession must therefore embrace these tenets of professionalization in order to ensure that media practice in Nigeria remains truly professional. And to remain truly professional, media practitioners should not only possess the following characteristics but must be seen by the society and the world as possessing them (Nwosu, 1996, p.245).

1. Must be seen to be performing a unique and essential service in Nigeria and beyond.

2. Must emphasize acquisition of broad knowledge and intellectualism.

3. Must have a specified period of specialized training to acquire systematically a unique body of knowledge based on research and skills acquisition in mass media.

4. Must ensure that media practitioners in Nigeria gains and retains a broad range of autonomy.

5. Must accept broad personal responsibility for other judgment and actions.

6. Should place greater emphasis on service than on private economic gain, in line with the business social responsibility concept.

7. Must encourage professional bodies and agencies to grow into comprehensive, self governing and selfreliant organizations.

8. Must abide by our codes of ethics and ensure that they have practical applications. 
These eight-point index for the attainment and sustenance of professionalism in mass media practice in Nigeria, according to Nwosu( 1996) were developed, synthesized, and contextually modified from the 24-point professionalism index introduced by Jack Mcdeod and Searl Hawley (1964) and modified by others (Windahl, 1975). Mass media practitioners should look at these eight points as cardinal sign-posts for the continued improvement of the mass media profession in this country. Individually and collectively, they have a duty to ensure, that the professional ideals inherent in each of these eight points continue to guide media practice in Nigeria.

\section{METHODOLOGY}

Both qualitative and quantitative research methods were adopted for this study. Under the qualitative approach, the Focus Group Discussion (FGD) method was adopted; while articles, essays, and opinions written on the subject matter were dialectically perused and synthesized, for the quantitative aspect.

The area of study is Anambra state of Nigeria, while the population of interest is 324(NUJ, 2015) registered practicing journalists in Anambra state. Using the Taro Yameni's formula, a sample size of 179 journalists was determined for the study. However, due the experts' (Nwodu,2006, Nwosu, 1999) views that 10-15 participants are suitable for a Focus Group Discussion session, a sample size of 45 was judgmentally selected for this study.

One FGD session was held in each of the three senatorial districts that make up the study area(Awka, for Anambra Central district; Onitsha for Anambra North district; and Nnewi for the South district. The research instrument used was the interview guide, while the explanation building technique method was the method of data presentation used.

The FGD sessions took place at Awka, at the government house press crew office on $4^{\text {th }}$ January, 2016; at Nnewi, at the office of the Information Officer, Nnewi North LGA, on 8th January, 2016; and at Onitsha, at the Anambra Broadcasting Service (TV) office, Awada, on $15^{\text {th }}$ January, 2016. At each of the sessions, 12 participants were involved. The researchers moderated the FGD sessions while the participants were given exercise books and biros to write down their comments.

\section{THE RESULT:}

- Who are the media Practitioners? The participants were unanimous in their answers that media practitioners are graduate journalism/mass communication persons who work in the mass media industries as journalists, editors, and photographers. They are the people who write the news, articles, features, advertisements, opinions and cartoons in the newspapers and magazines and the people who act as radio/ TV presenters, newscasters, news writers, editors, and programme presenters.

- Are media practitioners professionals? Again, all the participants agreed that media practitioners are professionals. However, half of the participants are ignorant of what makes a career a profession. They also agreed that, the NUJ and the NPC act as regulatory bodies but have not successfully taken control of the entry qualification for the career.

Furthermore, the participants described the code of ethics of the NUJ as a "paper tiger" as there is no strict monitoring of compliance.

- Is journalism a profession? Few of the participants explained that although journalism does not meet all the 8 point criteria, it is still in the process of being a profession, having achieved over $70 \%$ of the laid down criteria. Others were silent

\section{CONCLUSION}

Evaluating the Nigeria Media practice, as presently constituted, with the requirements of professionalism, one would not but agree with the view expressed by Adaja (2011) that, "the Nigerian Media cannot be fully referred to as a profession". Although, the Nigeria Union of Journalists parades a code of Conduct in which in its article 1 (i) referred to the union as a professional body as well as a trade union (Nnaemeka et al, 1989, p.276). The code however failed to state or identify the body of knowledge to be imbibed by it's members. Again, the membership provision was so loose that any body that has any thing to do with media organization can call him/herself a journalist. The provision provides for public relations Officers/Practitioners, those who are employed as editorial staff, those who had completed a probationary period of 12 months, etc to be called journalists, without stating any minimum qualifications. Also, no acceptable body to all the stakeholders who created or established to regulate the practice of journalism and enforce its rules and regulation in Nigeria as done in other advanced countries of the world. For example, in 1957, Britain established the National Council for the Training of the Journalists (NCTJ). The body was charged with the task of securing minimum standard for journalism practitioners. The body, subsequently, introduced a qualifying examination, the proficiency test, as a measure of control and career advancement. According to Boyd-Barret (1980, p.323): The purpose of the proficiency test was to indicate the completion of training during the apprenticeship period, 
and thus to qualify the holder of a proficiency certificate for advancement to the status of senior journalist and its associated salary advantages.

The National Council for the Training of Journalists (NCTJ) provided that candidates must have passed four basic subjects of English language, law, public administration and shorthand before admitting such candidates for the proficiency test. Although, emphasis was placed on apprenticeship; the on-the-job-training was designed to lead to some visible goals in form of passing an examination. At the same time, the apprenticeship was expected to last for 30 months, so as to regulate the practice of journalism in the land. This is very much unlike the Nigeria Union of Journalists (NUJ) provision of 12 months and without any qualifying examination (Nnemeka, 1989).

Again, the practice of journalism in Nigeria has been characterized by flaws that had prevented it from being referred to as a profession. At inception, the Nigeria media space was occupied by practitioners who neither saw themselves as professionals nor made professionalism their watchword. The first newspaper in Nigeria, Iwe Iroyin fun Awon Ara Egba ati Yoruba, was established by Rev. Henry Townsend who never had the opportunity of attending a school journalism. He never belonged or subscribed to any known body of known body of knowledge and never practice journalism. The closet experience he had was that "watched" his brother established a newspaper in one of the British Colonies before coming to Nigeria. Evidently, the foundation of journalism in Nigeria was erected on the wrong footing. And, if the foundation be destroyed, what can the righteous do. (Ps 11:3).

It is instructive to note that the Nigeria Journalist have been in perpetual fluid drifting from neutrality to partisan politics both in the period proceeding independence and after. Before independence, Nigeria journalism landscape was polarized along ownership structure. Although, Nigeria Journalists worked together to fight a common enemy, the colonial master, in the 1920s, 1930s and 1940s, the creation of the three regions brought about ownership/party loyalty and affiliation. Journalist and media organizations jettisoned their professional tenets of neutrality, objectivity, impartiality, etc, to look on the grab of partisan politics. Journalist shifted allegiance to their owners, region as well as the dominant party or Government of the region. Media organizations and journalist became divided among the three major parties -the NPC, NCNC and AG, Journalist, thus , became politically - minded and politically - partisan to the extent that all the allusions to professional standards were consigned into the dust bin.

Again, the liberalization and commercialization policy of the federal Government of Nigeria of the 1980s and 1990s threw a lot of challenges to the professional standard of journalism practice in Nigeria. The police made all forms of news coverage to be evaluated from the commercial point of view. The impact of the policy became noticeable on journalist' sense of news judgment, especially in the broadcast media. News event not sponsored were hardly aired. According to Oso (2012):

The Journalist is not allowed the autonomy and detachment required for the practice of his trade. His professional judgment has been compromised. The sale of news is killing professionalism in Nigeria. Broadcast journalism. Of a truth, commercialization of broadcasting has contributed to the dearth of serious journalism in Nigeria broadcasting.

The commercialization phenomenon posed a lot of challenges to the credibility of the news stories reported by journalists because stories of event are usually arranged to suit their sponsors. Usually, the stories "add nothing tangible to the quality of life of the people" and "there is nothing journalistically newsworthy about them" (Oso, 2012).

Furthermore, the issue of role conflict (that is dual roles) has seriously affected the output of the average Nigerian Journalist. The oscillation between the professional requirement of objectivity, neutrality partiality, etc. and the societal norms and values, especially the social responsibility theory, has made journalism in Nigeria to be in a perpetual state of flux. Journalists usually engage in a "constant war of independence" (ie. Between two worlds of "patriotic journalism (respective)" and "professional journalism (perspective)". This crises of identity" has married the integrity and credibility of journalism. According to Tsfaty and Libio (2003) as cited by Zandberg and Neiger (2005, p.139): “....Journalists' identities are not fixed and clear but fluid and unstable, and we see journalists as neither members of the professional community nor members of the national - hegemonic community - but as moving constantly between them".

\section{REFERENCES}

[1]. Adaja, I.A.(2011). The Nigeria media and the Quest for probity and Accountability in Governance. AAU: African studies Review Vol.10, pp183-204.

[2]. Adaja, A.I. (2012). Nigeria Journalism and professionalism: issues and challenges. In New media and mass communication Vol 5 ppl5-21. https:1lwww.ute.org.accessed $29^{\text {th }}$ December 2015.

[3]. Ansari, M.N. (2011). Information Requirements of Pakistari Media Practitionners: A comparative study. Newspapers indaho edu. 11 naserean internail. 
[4]. Answer. Com. www.answer.com>answer.com>wki>

[5]. Answer $>$ categories $>$ literature and languages $>$ language and authors $>$ English language $>$ definition.

[6]. Astor, J.J. (1991). Art of Modern Journalism. Delhi: Akashdeep Publishing

[7]. Bel. Molokwu, J. and De-Aguoma. C. (1990).Professional in journalism and Press Freedom in Nigerian In I.E. Nwosu (Ed).Mass communication and National Development. Aba: frontiers Publishers Ltd. Pp 301-312.

[8]. Boyd-Barret, O. (1980). The politics of socialization: Recruitment and Training for journalists. In H. Christian (Ed). The sociology of journalism and the press-sociological Review monograph 29, 307-340.

[9]. Eke Anyawu T.N. and Obianigwe, N. (2012). The Nigeria Press, brown envelop syndrome and the media professionalism: The Missing Link. In Journalism and mass Communication, Vol. 2 No. 4 pp. 514 - 530.

[10]. Fab. Ukozor, N. (2011). Ethical Responsibility and professionalism in journalism practice, in V. Agbanu and C. Nwabueze (Eds). Readings in Mass Communication-Global perspectives communication issues (pp 291-299). Enugu. Rhyce-kerex publishers Ltd.

[11]. Falorin, B. (1998). Theories of mass communication: An introductory Test. Ibadon: Stirling-Horden Publishers (Nig.) Ltd.

[12]. Ndolo, I.S. (2010). Mass media: Systems and society. Enugu: Phycee Kerex publishers Ltd.

[13]. Nnaemeka, T., Uvieghara, E. and Uyo, D. (1989). Philosophy and Dimensions of National Communication Policy. Vol.2. Lagos: centre for Black and African Arts and civilization.

[14]. Nwosu, I.E. (1996). Advertising Professionalization and Regulation in Nigeria. In I.E. Nwosu and U. Ekwo (Eds). Mass Media and Marketing Communications. Principles Perspectives and Practice pp 237260.

[15]. Odunewu, A. (2000). White and Professionalism. In L. Arogundade and B. Eitokpah (Eds). Media in a civil economy. Thought and perspentives (ppl-21). Lagos: International Press centre and Fredrich Elbert stifthing.

[16]. Olajide F., Talabi, B., and Ogudeji K. (2012). Effects of non-professionalism in Nigeria Journalism in Global Journal of Human and Social Science Vol. 12 Issue 7 USA: Global Journal Incorporated ISE.

[17]. Oloyede, J. (2003). Nigeria Journalism and Professionalism: a case of the journalists in Osun State. Unpublished Project.

[18]. Onah, J.O. (1996). Professionalism in Public Relationship-The Role of Public Relations in Modern Marketing. In E.I. Nwosu and U. Ekwo (Eds) Mass Media and Marketing Communication. Principles, perspectives and Practitioners pp 217-236. Enugu: Thought communication publishers.

[19]. Oso, L. (2012). News for sale: The challenges and implications of the commercialization of News in Nigeria. In L. Oso, D. Soola, and U. Pate (Eds). Media Governance and Development: Issues and Trades (pp83-104) KG, Saarbrucken, Germany: LAPI AMBERT Academy.

[20]. The Holy Bible (2006). Authorized King James Version. South Korea: Holman Bible Publishers.

[21]. Tsebee, K.A. (2012). Media Ethics: Professionalism coverage of the APO Killings in Abuja Nigeria. Journal of Communication Culture Vol. 2 No. 3 Pp. 1-8.

[22]. Udoakah, N., and Nnadi, A. F. (2007). Editorial Policies and Journalism Practice in Nigeria. International Journalism of Communication. UNN

[23]. Zandberg, E and Neiger M. (2005). Between the nation and the profession: Journalists as members of comradiating communities. Media culture and society, Vol27 (i)m131-141. 